\title{
Empowerment Community: Pembentukan Komunitas Peduli Lingkungan Sebagai Upaya Peningkatan Kesadaran Bencana \& Kesehatan pada Warga Bantar Kali di Kampung Payung Kertas, Malang
}

\author{
Lusy Asa Akhrani, Ika Herani, Alfrina Hany \\ Universitas Brawijaya, Malang, Indonesia \\ lusyasa@ub.ac.id
}

Received: $11^{\text {th }}$ November $2020 \mid$ Accepted: $21^{\text {th }}$ July $2021 \mid$ Published: $27^{\text {th }}$ July 2021

\begin{abstract}
\begin{tabular}{l}
\hline Key word: \\
\hline Empowerment \\
\hline Community; \\
Community; \\
Disaster \\
Awareness; \\
Health \\
\\
\\
\hline
\end{tabular}
Kata Kunci

Guru;

Sekolah Luar

Biasa;

Anak

Berkebutuhan

Khusus;

Bahasa dan

Bicara

\section{Abstract}

Payung Kertas Village located at Pandanwangi Village, on the bank of the Bango river. The preliminary research showed that the environmental care behavior of residents of the riverbank area is to be low considering. Many residents choose to throw garbage directly in the river, construction residential houses in the Kali Sari watershed, and several indicator of the lack of environmental awareness of watershed residents. Awarenessraising will be easier to do when activities are started, designed, and carried out by communities with social problems. The aims of this community service is to empower communities to solve social problems. The formation of environmentally conscious communities is carried out through a tiered process by encouraging active citizen involvement. The method used in the fomation rof environmental care communities is carried out with a social intervention approach that utilizes action research. Social change is carried out by emphasizing three stages namely the planning, implementation, and evaluation stages. As a result of this community service, a community caring for the environment was formed with the first movement in the form of sorting waste from inside the house, synergizing with waste transport officers, and periodically monitoring and evaluating the implementation of the environmental care movement.

\section{Abstrak}

Kampung Payung Kertas berlokasi di tepi aliran sungai Bango, kelurahan Pandanwangi. Hasil penelitian awal menunjukkan perilaku peduli lingkungan warga daerah bantaran sungai dapat dikatakan rendah mengingat masih banyak warga memilih membuang sampah langsung di sungai, pembangunan rumah huni di DAS Kali Sari, dan beberapa indikator dari kurangnya kepedulian lingkungan warga daerah aliran sungai. Peningkatan kesadaran akan lebih mudah dikerjakan bila kegiatan dimulai, dirancang dan dikerjakan oleh komunitas yang memiliki masalah sosial. Itu sebabnya sangat penting membentuk empowerment community untuk menyelesaikan masalah sosial yang dihadapi komunitas. Metode yang digunakan dalam pembentukan komunitas peduli lingkungan dilakukan dengan pendekatan intervensi sosial yang memanfaatkan action research yaitu perubahan sosial dilakukan dengan menekankan tiga tahap action yang berputar terus sampai perubahan yang diinginkan tercapai yaitu tahap perencanaan, pelaksanaan dan
\end{abstract}


evaluasi. Hasil pengabdian masyarakat ini terbentuk komunitas peduli lingkungan kampung payung kertas dengan gerakan pertama berupa pemilahan sampah dari dalam rumah, bersinergi dengan petugas pengangkutan sampah dan secara berkala melakukan monitoring dan evaluasi terhadap pelaksanaan gerakan peduli lingkungan.

\section{PENDAHULUAN}

Sungai merupakan aliran air yang besar dan memanjang yang mengalir secara terus-menerus dari hulu (sumber) menuju hilir (muara). Tak dapat dipungkiri Indonesia sebagai negara dengan 5.950 daerah aliran sungai (DAS) seringkali memanfaatkan sungai dalam kehidupan sehari-hari seperti untuk irigasi pertanian, bahan baku air minum, sebagai saluran pembuangan air hujan dan air limbah, bahkan sebenarnya potensial untuk dijadikan objek wisata sungai seperti wisata tubbing. Kota Malang sendiri memiliki beberapa aliran sungai yang membelah pemukiman warga, namun kondisi sungai tersebut semakin tercemar dari tahun ke tahun. Gambar 1 berikut ini adalah gambaran kondisi sungai di Malang yang diambil dari sumber Malang Voice (2019).

Kurangnya kesadaran lingkungan warga bantaran kali sangat memungkinkan peningkatan kondisi tercemar sungai. Sungai di Kota Malang terindikasi mulai tercemar. Bukan hanya limbah bahan berbahaya dan beracun (B3) saja, sampah industri maupun rumah tangga turut mencemari sungai (Cahyono, 2018). Setidaknya ada 26 titik dari 27 titik sungai di Kota Malang yang terpantau kritis. Hal itu berdasarkan pemantauan Dinas Lingkungan Hidup (DLH) Kota Malang.

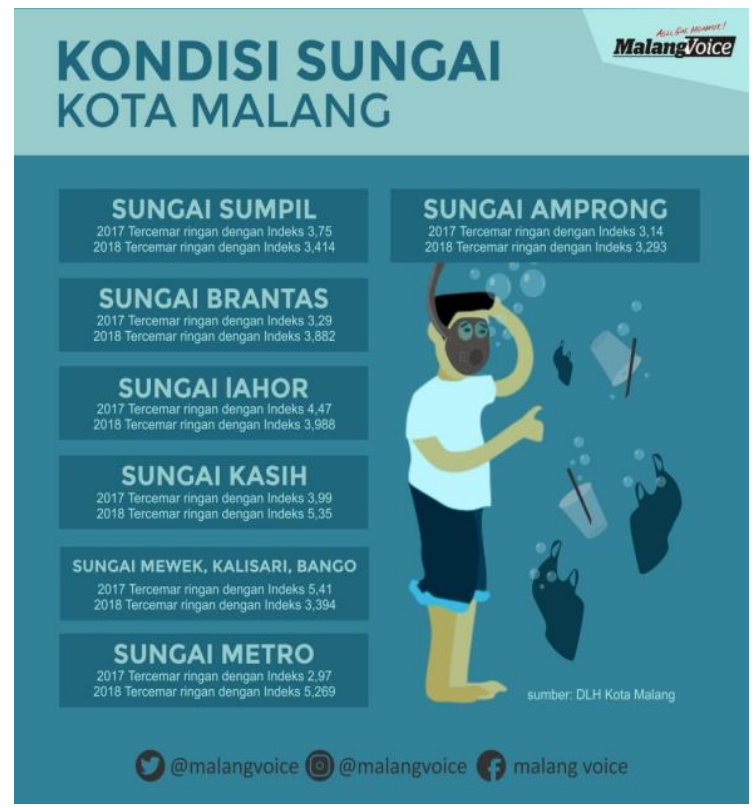

Gambar 1. Kondisi Sungai Kota Malang

Kondisi kritis sungai dapat menimbulkan bencana alam seperti tanah longsor, banjir, kualitas air tanah yang buruk, menimbulkan berbagai penyakit yang dapat mengancam kesehatan warga. Melakukan aksi setelah bencana terjadi bukanlah solusi, dibutuhkan upaya prevensi dan promosi yang baik dalam penangkalan bencana. Itu sebabnya pengetahuan tentang kebencanaan sebaiknya diberikan sedini mungkin, karena pengetahuan kebencanaan yang baik akan mempengaruhi perilaku, kebiasaan dan langkah seseorang saat 
dewasa dalam bereaksi pada kejadian bencana (BPBD Kota Malang, 2019)

Menurut BPBD Kota Malang (2019), pengetahuan tentang kebencanaan adalah keniscayaan mengingat Indonesia adalah negara yang rawan bencana. Pengetahuan kebencanaan berguna dalam menghadapi bencana yang dapat terjadi sewaktu-waktu. BPBD kota Malang mencatat setidaknya 119 bangunan rusak, 18 orang mengalami luka-luka dan 61 lainnya terpaksa mengungsi akibat bencana yang terjadi, serta 13 hewan ternak mati. Bencana bukan saja terjadi akibat perubahan alam, ada pula andil manusia dalam bencana. Menurut teori person in context Lewin (1951), perilaku adalah fungsi dari manusia, lingkungan dan interaksi antara manusia dan lingkungan tersebut. Dalam konteks bencana alam dijelaskan bahwa bencana bisa saja terjadi karena faktor alam seperti iklim atau perubahan alam, perilaku manusia yang menyebabkan bencana dan dapat pula terjadi akibat interaksi manusia dan alam. Perilaku manusia dapat mengakibatkan bencana, begitu pula perubahan alam dapat mengakibatkan bencana bagi manusia. Bagi warga bantaran kali seringkali banjir, longsor di DAS akibat perilaku manusia menutup jalan air demi pondasi rumah tinggal dan kebiasaan membuang sampah di sungai.
Sama seperti daerah aliran sungai lainnya, RT 04 kampung payung kertas yang terletak di tepi sungai Kalisari setiap tahun di musim hujan selalu menjadi daerah rawan bencana. Bencana banjir, longsor, dan wabah demam berdarah menjadi masalah yang selalu dihadapi warga. Bahkan saat hujan tidak turun, tumpukan sampah yang dibuang warga di aliran sungai tidak terbawa aliran sungai menimbulkan bau dan mengancam kesehatan warga. Namun demikian bencana tak pernah membuat warga menjadi sadar untuk mengubah perilaku lingkungan mereka, warga tetap membuang sampah di sungai atau membuang di lahan kosong meskipun sudah ada TPS atau petugas kebersihan. Kesadaran menjaga lingkungan yang masih minim membuat perilaku tersebut tidak berubah.

Warga RT 04 kampung payung kertas sebenarnya sudah berusaha untuk mencegah perilaku membuang sampah di sungai warga dengan menetapkan denda Rp500.000 untuk warga yang ketahuan membuang sampah di sungai, namun mekanisme sanksi yang tidak jelas membuat warga tetap membuang sampah di bantaran sungai. Pemberian sanksi dan program menjadi tidak efektif tanpa diikuti keterlibatan aktif warga dalam setiap proses perubahan. Hal ini menjadikan pendekatan intervensi sosial menjadi 
penting dilakukan untuk mencapai perubahan untuk menyelesaikan masalah lingkungan. Berikut ini adalah gambaran lingkungan RT 04 Kampung Payung Kertas, Kelurahan Pandanwangi.

Warga kampung payung kertas RT 04, kelurahan Pandanwangi tinggal di pemukiman padat di tepi/ aliran sungai Kalisari. Permasalahan ketidakpedulian pada lingkungan, kurangnya kesadaran hidup sehat membuat warga melakukan perilaku yang dapat mendatangkan bencana bagi warga maupun kampung lain di hilir sungai. Setiap musim hujan bencana longsor daerah aliran sungai akibat tidak ada penataan dan perawatan luas/ lebar sungai, banjir akibat luapan hujan dan tersumbatnya sungai dengan sampah dan pondasi rumah, wabah penyakit yang siap mengintai seperti demam berdarah dan penyakit ringan seperti flu dan pencernaan akibat kurang bersihnya lingkungan rumah. Sedangkan musim kemarau menimbulkan bau tidak sedap akibat sampah yang bertumpuk di sungai maupun yang dibuang dan tak terangkut di lahan-lahan kosong dekat daerah hunian.

Kesadaran dan kepedulian lingkungan tidak dapat tumbuh tanpa keinginan dan dorongan internal. Akan menjadi sia-sia edukasi dari pihak eksternal komunitas tanpa keinginan berubah dari internal komunitas. Dibutuhkan gerakan bersama komunitas dalam mencapai perubahan perilaku dan lingkungan. Itu sebabnya dibutuhkan pembentukan empowerment community dimana komunitas aktif bergerak dan berdaya menyelesaikan masalah sosial yang ada dalam komunitas. Pembentukan komunitas tidak semudah mengumpulkan warga dan membentuk kelompok, dibutuhkan pendekatan yang intens dan sesuai dengan gaya komunikasi dan tidak melanggar nilai-nilai komunitas untuk mencapai penerimaan dan kesepakatan dalam membentuk empowerment community. Pendekatan terhadap komunitas dengan mendatangi kelompok-kelompok dalam komunitas, berkegiatan bersama dan menjadikan diri sebagai bagian dari komunitas agar dapat berdiskusi dan mendorong perubahan dari dalam komunitas.

\section{Pembentukan}

empowerment community menjadi awal solusi menyelesaikan permasalahan lingkungan di dalam komunitas. Keterlibatan aktif warga di setiap tahapan perubahan menjadikan warga bertanggung jawab pada penyebab dan akibat yang dihasilkan masalah sosial dalam komunitas. Action research merupakan pendekatan yang membuat komunitas berdaya, membuat komunitas bergerak dalam setiap tahapan perubahan yang akan dilakukan. 


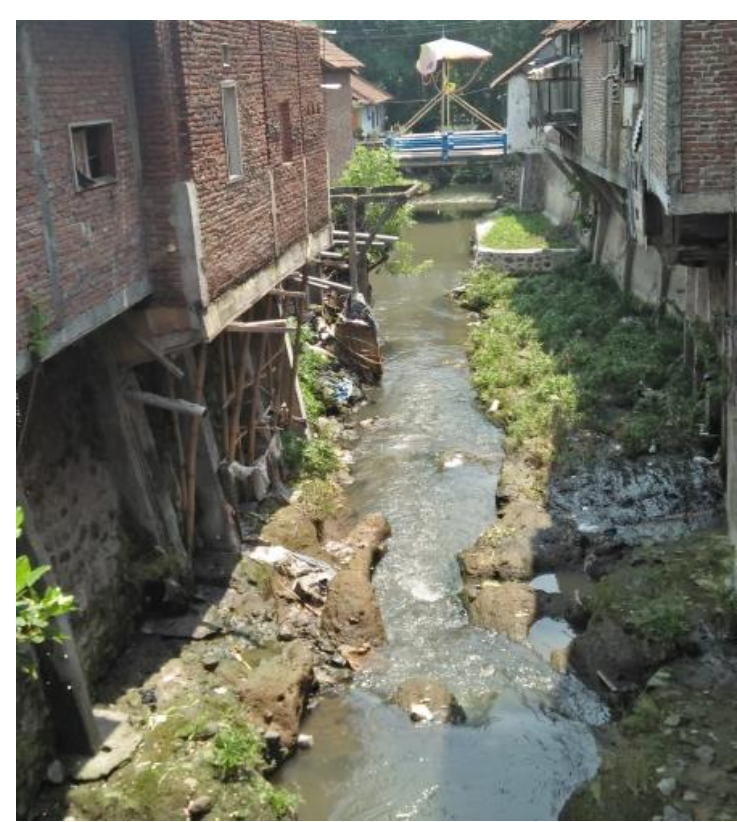

Gambar 2. Pondasi dan bangunan rumah tinggal yang menutup dan mempersempit badan sungai

Tujuan pengabdian masyarakat ini adalah untuk membentuk komunitas yang berdaya/ empowerment community yang tanggap terhadap bencana di lingkungannya dengan meningkatkan kepedulian lingkungan pada warga. Empowerment community adalah salah satu bentuk pemberdayaan masyarakat. Tujuan utama dalam Empowerment community agar masyarakat memiliki kemampuan dan kemandirian baik secara ekonomi, ekologi dan sosial. empowerment community memberikan perencanaan dan memutuskan untuk mengelola sumber daya lokal yang dimiliki. Konsep empowerment communityt sendiri merupakan salah satu proses yang memberikan fasilitas guna mendorong masyarakat untuk memanfaatkan lingkungan yang strategis agar bisa berkelanjutan dalam jangka waktu yang lebih panjang.

Konsep empowerment community muncul akibat dengan dua faktor, yaitu dengan adanya kegagalan dan juga harapan. Kegagalan dalam pembangunan ekonomi untuk menanggulangi kemiskinan dan lingkungan berkelanjutan. Harapan muncul akibat alternatif-alternatif pembangunan berkaitan dengan demokrasi, persamaan gender, pesan generasi berkelanjutan dan pertumbuhan ekonomi yang memadai (Pranaka \& Prijono, 1996). Empowerment community adalah kekuatan ekonomi dikaitkan dengan informasi, pengetahuan dan keterampilan, partisipasi, dalam sebuah organisasi yang bersumber pada keuangan. Maka dari itu memastikan dengan baik di setiap kegiatan yang bermanfaat bagi masyarakat guna meningkatkan pemberdayaan masyarakat sangat penting dilakukan dalam community empowerment.

Empowerment community lakukan dengan beberapa tahap. Seperti dengan tahap seleksi lokasi, sosial pemberdayaan masyarakat, proses pemberdayaan masyarakat, kemandirian masyarakat. Sedangkan untuk proses pemberdayaan masyarakat sendiri masih berdiri dengan berbagai faktor seperti dengan kajian keadaan pedesaan partisipasi, pengembangan kelompok, penyusunan 
rencana pelaksanaan kegiatan, monitoring dan evaluasi. Dengan begitu semakin terkonsep semua yang dikerjakan semakin mungkin ketika masyarakat semakin diberdayakan. Community empowerment berarti suatu komunitas memiliki sumber daya dan bakat untuk mengelola urusannya, untuk mengendalikan dan mempengaruhi kelompok dan kekuatan yang relevan di dalam dan di luar komunitas, dan untuk mengembangkan para pemimpin dan organisasi masyarakat yang berdaya. Salah satu contoh pengembangan pemimpin yang diberdayakan adalah anggota masyarakat belajar untuk mengatur sehingga mereka dapat mengambil bagian dalam meningkatkan komunitas mereka dan mengambil tindakan terhadap peningkatan ini. Empowerment community sangat penting untuk membangun kembali masyarakat setelah trauma, seperti selamat dari bencana alam, atau untuk individu di negara yang dilanda perang (Anckermann dkk., 2005).

\section{Empowerment community bekerja} melalui peningkatan pengaruh masyarakat terhadap struktur dan kebijakan yang mempengaruhi pengalaman hidup masyarakat dan anggotanya. Peningkatan pengaruh sering terjadi melalui kemitraan antara mereka yang berkuasa dan anggota masyarakat lainnya. Kemitraan ini dapat terjadi di dewan penasihat, koalisi, atau inisiatif inklusi masyarakat yang lebih luas (Fawcett dkk., 1994). Kadang-kadang, Empowerment community dapat berarti bahwa anggota masyarakat menjadi diberdayakan dengan bantuan para pemimpin masyarakat dan sebaliknya. "Pemberdayaan bersama" seperti itu mungkin menantang, namun dapat sangat bermanfaat bagi masyarakat (Bond \& Keys, 1993).

Target luaran program pengabdian masyarakat ini adalah meningkatnya kesadaran warga DAS Kali Sari, Kampung Payung Kertas, RT 04, Kelurahan Pandawangi Malang tapa lingkungan dengan membentuk Empowerment community. Komunitas warga DAS Kali Sari ini yang akan menggerakan dan memberdayakan anggota komunitas dengan intense melakukan gerakan peduli lingkungan, membuat aturan mengikat pada anggota komunitas dan melakukan evaluasi. Menyadari dan merasa memiliki lingkungan harus dibangun dari dalam (internal) komunitas agar gerakan dapat berkembang dan terus melakukan gerakan peduli lingkungan DAS.

\section{METODE}

Tim Pengabdi menggunakan action research sebagai teknik yang digunakan dalam program intervensi sosial. Menurut Gunawan, action research adalah kegiatan 
dan atau tindakan perbaikan sesuatu yang perencanaan, pelaksanaan, dan evaluasinya digarap secara sistematik dan sistematik sehingga validitas dan reliabilitasnya mencapai tingkatan riset (Asmara \& Nugroho, 2017). Action research juga merupakan proses yang mencakup siklus aksi, yang mendasarkan pada refleksi; umpan balik (feedback); bukti (evidence); dan evaluasi atas aksi sebelumnya dan situasi sekarang. Penelitian tindakan ditujukan untuk memberikan andil pada pemecahan masalah praktis dalam situasi problematik yang mendesak dan pada pencapaian tujuan ilmu sosial melalui kolaborasi patungan dalam rangka kerja etis yang saling berterima (Hairunisya, 2017).

Action research digunakan untuk menggerakan komunitas. Menjadikan komunitas bergerak dan berdaya, diimbangi dengan berbagai cara dalam mendorong warga berdaya seperti edukasi dan sosialisasi yang tak terputus, membentuk agen-agen sosial yang bersedia menggerakan komunitas, memetakan permasalahan dan menciptakan solusi bersama yang akan dikerjakan bersamasama. Komunitas dibutuhkan sebagai pendekatan untuk memecahkan masalah terkait dengan perilaku manusia, dengan titik berat upaya pengembangan manusia dan memanfaatkan sumber daya lingkungan sehingga dapat berkontribusi dari upaya pencegahan/ mengurangi masalah(Afandi dkk., 2012). Selain itu pendekatan komunitas merupakan usaha mencari alternatif kasus penyimpangan perilaku manusia dari norma-norma sosial, upaya mendukung hak setiap manusia untuk berbeda tanpa harus mengalami sanksi psikologis dan resiko kerugian material (Rapaport, 77). Orford (1992) menjelaskan bahwa ilmu psikologi dapat digunakan dalam pendekatan komunitas yaitu untuk memahami dan membantu meningkatkan kesejahteraan orang-orang dalam suatu sistem sosial dan dalam keseharian kehidupan alamiah (lingkungan dan konteks sosial).

Sebelum pendekatan action dilaksanakan, tim pengabdian masyarakat melakukan penelitian awal terlebih dahulu dengan melakukan observasi dan wawancara pada warga kampung payung kertas, RW 3, Pandanwangi. Setelah itu tahapan action research dilaksanakan. Action research merupakan pendekatan dalam psikologi sosial terapan. Action research adalah proses cyclical (berputar) yang mencakup tiga tahap yaitu perencanaan, perubahan dan evaluasi. 


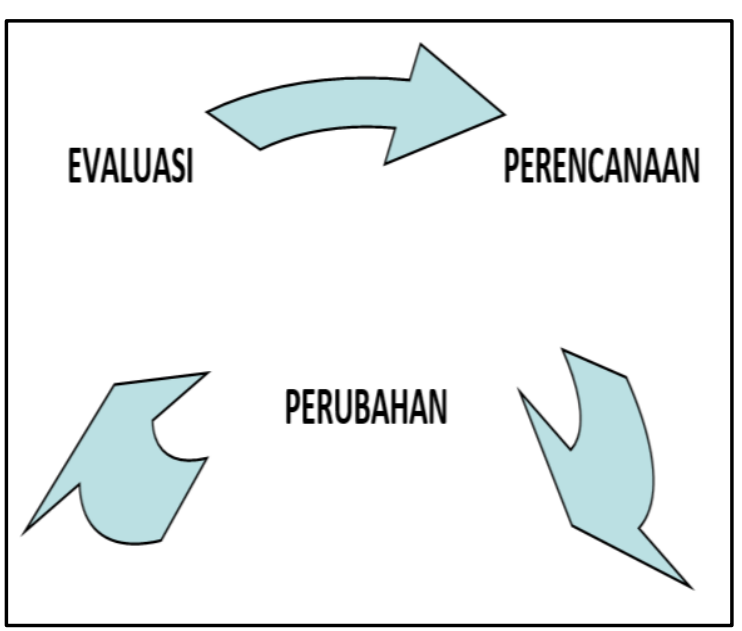

Gambar 3. Alur cycling action research

Hasil yang ditargetkan action research adalah feedback terhadap semua yang terkait masalah sosial dan penemuan baru sampai dengan teori baru dalam penyelesaian masalah sosial. Dalam psikologi sosial terapan tim pengabdi adalah partisipan yang memiliki tujuan dalam action research yaitu memecahkan masalah, memperoleh pengetahuan dan teori baru dengan menggunakan action theory. Dalam suatu intervensi sosial, intervionis harus mengecek secara terus menerus untuk melihat perlu/ tidaknya dilakukan perubahan perlakuan setelah melihat situasi yang ada (sangat situasional). Social action dilakukan untuk meringankan/ menyelesaikan masalah sosial melalui usaha-usaha kolektif yang terorganisasi untuk mencapai perubahan. Perubahan dilakukan secara sistematis, terarah, dan berkesinambungan dengan berorientasi pada komunitas.
Action research dalam implementasinya berpedoman pada tahapan LFA yaitu The Logical Framework Approach. LFA menekankan keterkaitan logis pada input, rencana kegiatan, dan hasil yang diharapkan. LFA adalah alat analisis perencanaan dan management proyek yang berorientasi pada tujuan dengan tiga kuncinya yaitu berorientasi pada tujuan, berorientasi pada kelompok sasaran dan partisipatif. LFA sendiri memiliki lima struktur berjenjang dari tujuan jangka pendek sampai dengan jangka panjang yang harus diwujudkan dengan sistematis. Lima struktur LFA tersebut adalah (1) Inputs yaitu sumberdaya dapat berupa uang, bahan, materi, barang, orang, infrastruktur dan sebagainya yang dibutuhkan untuk memulai dan menjalankan program, (2) Activities (kegiatan) yaitu kegiatan-kegiatan yang harus dilakukan oleh proyek agar outputs yang direncanakan dapat diperoleh, (3) Outputs yaitu hasil yang harus dicapai, yang dibutuhkan agar tujuan spesifik program (purpose) tercapai. Outputs langsung dalam control manajemen program sehingga harus dijamin pencapaiannya agar program berhasil, (4) Immediate Objectivel project objectivel specific objective atau purpose yaitu tujuan specific diharapkan dapat dicapai sebagai hasil dari pelaksanaan program/ proyek 
dan dapat bersifat kualitatif/kuantitatif. Impak yang diharapkan terjadi pada saat program/ proyek selesai, dan merupakan sasaran praktis dan riil dari program, tidak langsung dalam control manajemen program, sehingga tidak dapat dijamin $100 \%$ pencapaiannya oleh manajemen, (5) Development Objectivel wider objectivel overall aim/ overall goal berupa tujuan umum yang tidak secara langsung dicapai oleh proyek, tapi proyek diharapkan dapat memberikan kontribusi terhadap pencapaian tujuan ini, berada diluar control dan pengaruh langsung dari proyek.

LFA memiliki beberapa analisis yang harus dilakukan dalam memetakan masalah dalam komunitas yaitu analisis situasi dan project matrix. Analisis situasi yang terdiri dari:

a. analisis partisipan yaitu tim pengabdi melakukan analisis pada orang-orang yang berkepentingan baik langsung/ tidak langsung atas isu/ masalah sosial, ini dilakukan untuk memudahkan identifikasi teman atau musuh dalam komunitas,

b. analisis masalah yaitu dengan menganalisis dan mengidentifikasi masalah dan penyebabnya dalam memformulasikan masalah harus diingat dua hal yaitu identifikasi masalah yang ada (existing), bukan yang mungkin/ terbayang, dan formulasi masalah yaitu situasi negatif yang ada. Langkah berikutnya adalah memilih masalah utama (focal problem) dan menyusun pohon masalah (problem tree) dengan melihat hubungan sebab akibat dan terakhir adalah

c. analisis tujuan yaitu mentransformasikan pohon masalah yang sudah disusun ke pohon tujuan (objective tree), yaitu menciptakan solusi masalah yang bisa dilakukan, kemudian dianalisis. Project matrix merupakan bagian dari perencanaan proyek dari tujuan jangka pendek sampai dengan jangka panjang dan mempersiapkan semua input dan output yang harus diperhatikan dengan tetap memperhitungkan faktor internal dan eksternal yang dimiliki oleh komunitas.

Pembentukan community empowerment itu sendiri dimulai dari tahap awal yaitu perencanaan dimana perencanaan yang dibutuhkan dalam community empowerment ini adalah dengan melakukan analisis situasi seperti analisis partisipan dan analisis masalah. Setelah semua data pemetaan jelas, dan community empowerment terbentuk maka dilaksanakan analisis tujuan dengan merancang solusi-solusi masalah komunitas. Setelah analisis tujuan dilakukan maka dilakukan tahap kedua yaitu perubahan dengan 
mengimplementasikan semua solusi yang dirancang. Setelah implementasi terwujud maka tahap terakhir adalah evaluasi yaitu melakukan evaluasi program yang sudah dijalankan bersama, mengukur tingkat keberhasilan dan kegagalan untuk kemudian di rencanakan kembali perbaikan dan tiga proses ini terus berputar sampai perubahan yang diharapkan tercapai.

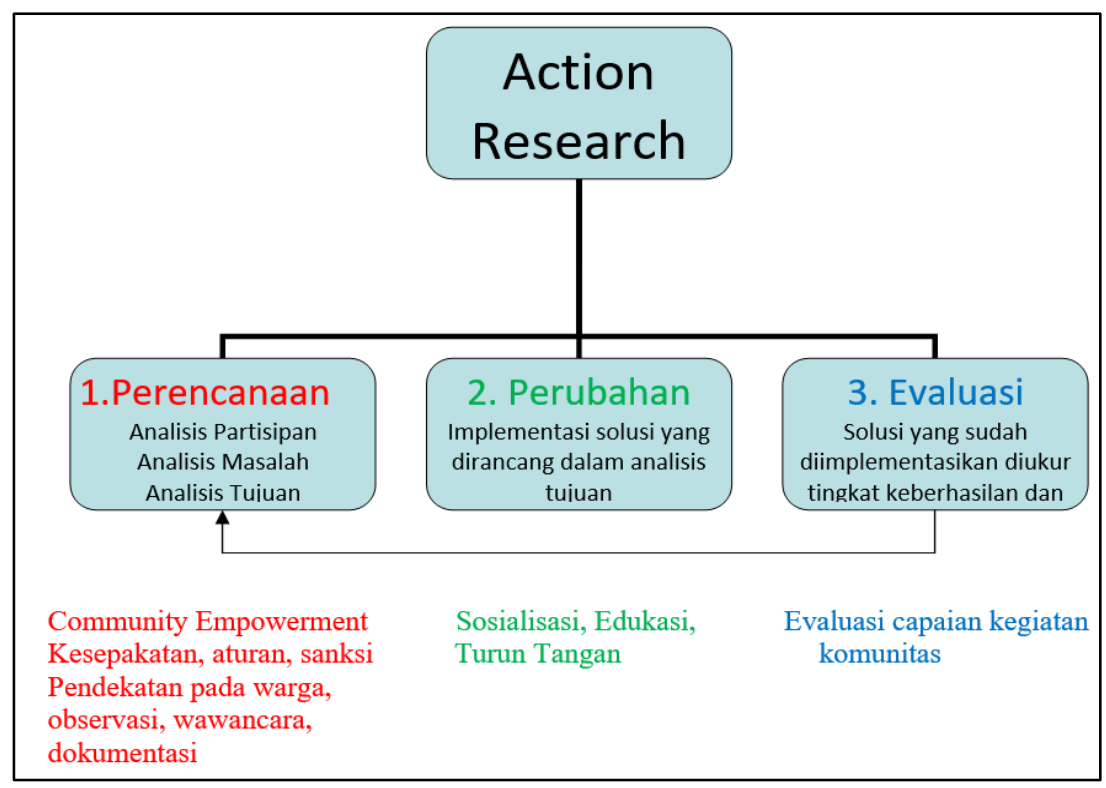

Gambar 4. Detail alur dan kegiatan dalam action research

Pembentukan community empowerment sendiri tidak mungkin dilakukan secara instan dan tidak berkelanjutan. Dibutuhkan kerjasama dengan berbagai pihak di luar komunitas untuk mendapatkan penerimaan komunitas terhadap tim pengabdian masyarakat. Pihak eksternal komunitas tersebut berperan sebagai mitra tim pengabdian masyarakat. Dalam pengabdian masyarakat ini mitra di luar komunitas adalah pihak kelurahan Pandanwangi sebagai otoritas pemerintahan yang akan memberikan legal kegiatan pengabdian masyarakat di kampung payung kertas, RW 3, Pandanwangi. Evaluasi program akan dilakukan melalui monitoring checklist indikator keberhasilan yang telah ditetapkan tim pengabdian masyarakat.

\section{HASIL}

\section{Perencanaan}

Tim Pengabdi menggunakan pendekatan action research. Action research merupakan pendekatan yang terdapat dalam intervensi sosial. Dalam suatu intervensi sosial, intervionis harus mengecek secara terus menerus untuk melihat perlu atau tidaknya dilakukan perubahan perlakuan setelah melihat situasi yang ada (sangat situasional). Tujuan utama dalam intervensi sosial itu sendiri 
menghasilkan perubahan. Sepanjang kegiatan pengabdian masyarakat Doktor Mengabdi ini, warga RT 04 yang mengikuti kegiatan awal dalam asesmen awal berjumlah 54 warga, sedang yang bersedia bergabung dalam komunitas berjumlah 17 warga, sedangkan pretest dan posttest dilakukan pada 11 warga.

Untuk mencapai perubahan dibutuhkan perencanaan yang matang dengan melakukan tiga analisis di dalamnya yaitu analisis partisipan, analisis masalah dan analisis tujuan.

Tabel 1. Analisis Partisipan

\begin{tabular}{|c|c|c|c|}
\hline Partisipan & $\begin{array}{c}\text { Kebutuhan } \\
\text { Need/Interest }\end{array}$ & $\begin{array}{c}\text { Potensi } \\
\text { Strength/Weakness }\end{array}$ & $\begin{array}{l}\text { Hubungan } \\
\text { Conflict/ } \\
\text { Dependency }\end{array}$ \\
\hline \multicolumn{4}{|l|}{ Individu } \\
\hline Ketua RT & Lingkungan bersih & Dituakan, memberi contoh & Dependency \\
\hline Tukang sampah & Menjalankan tugas & $\begin{array}{l}\text { Jadwal pengangkutan tidak pasti, } \\
\text { memilah sampah meski dari warga } \\
\text { tercampur }\end{array}$ & Dependency \\
\hline \multicolumn{4}{|l|}{ Masyarakat } \\
\hline Warga lain RT & Lingkungan bersih & $\begin{array}{l}\text { Mengabaikan kebersihan RT lain, banyak } \\
\text { home industri, membuang sampah di } \\
\text { sungai, tidak punya lahan parkir atau TPS }\end{array}$ & Conflict \\
\hline $\begin{array}{l}\text { Warga RT di luar } \\
\text { komunitas }\end{array}$ & Lingkungan bersih & $\begin{array}{l}\text { Belum memiliki kesadaran lingkungan, } \\
\text { keterbatasan waktu, kurang komunikasi }\end{array}$ & Grey area \\
\hline \multicolumn{4}{|l|}{ Organisasi/ } \\
\hline Karang Taruna & Pengakuan, eksistensi & $\begin{array}{l}\text { Apatis, kurang memiliki aktivitas } \\
\text { bersama yang memihak kepentingan } \\
\text { lingkungan } \\
\text { Mendukung kegiatan, memiliki power }\end{array}$ & $\begin{array}{c}\text { Grey area } \\
\text { Dependency }\end{array}$ \\
\hline
\end{tabular}

Berdasarkan tabel analisis partisipan perlu diwaspadai potensi konflik dengan warga di luar RT 04 karena kurangnya kesadaran dalam pengelolaan sampah, banyak yang langsung membuang sampah di sungai, a. Analisis Partisipan

Partisipan merupakan orang-orang yang berkepentingan baik langsung atau tidak langsung atas isu atau masalah sosial dalam komunitas. Untuk memudahkan identifikasi dapat menggunakan table partisipan. Dari tabel yang telah dibuat, maka harus ditentukan mana yang akan menjadi prioritas dalam perubahan. Hasil analisis partisipan dapat dilihat pada table 1 . 
sampah yang sekaligus berprofesi

sebagai pemulung, dan kelurahan

sebagai otoritas yang diakui. Sedangkan

yang membutuhkan usaha merangkul

untuk diajak bersama-sama melakukan

perubahan adalah warga RT 04 yang

belum tergabung dalam komunitas

peduli lingkungan kampung payung

kertas dan karang taruna RT 04.

b. Analisis Masalah

Melakukan analisis dengan
mengidentifikasi masalah dan

penyebabnya. Dalam memformulasikan

masalah tim pengabdi mengingat dua

hal:

1) Identifikasi masalah yang ada (existing), bukan yang mungkin/ terbayang/ yang akan datang
2) Formulasi bukan pernyataan tidak ada solusi tapi pernyataan situasi negatif yang ada. langkah berikutnya: memilih masalah utama (focal problem) dan menyusun pohon masalah (problem tree) dengan melihat hubungan sebab akibat.

c. Analisis Tujuan

Pada tahap ini pohon masalah yang sudah disusun ditransformasi ke pohon tujuan (objective tree), yaitu solusi masalah yang bisa dilakukan, kemudian dianalisis. Satu per satu masalah dianalisis sehingga diperoleh menjadi tujuan (objective) dengan memformulasi masalah menjadi pernyataan positif.

Tabel 2. Analisis Masalah dan Tujuan

\begin{tabular}{|c|c|c|c|}
\hline Sebab & Akibat & $\begin{array}{c}\text { Kegiatan yang harus } \\
\text { dilakukan }\end{array}$ & $\begin{array}{c}\text { Hasil yang } \\
\text { diharapkan }\end{array}$ \\
\hline $\begin{array}{l}\text { Warga belum sadar } \\
\text { lingkungan: buang sampah } \\
\text { di sungai, bakar sampah, } \\
\text { buang di luar rumah seperti } \\
\text { selokan dan jalan }\end{array}$ & $\begin{array}{l}\text { Lingkungan kotor, } \\
\text { sampah menumpuk, } \\
\text { bau, penyakit: flue, } \\
\text { DB, diare }\end{array}$ & $\begin{array}{l}\text { Sosialisasi kebersihan dan } \\
\text { kesehatan dengan diskusi dan } \\
\text { FGD, membentuk komunitas } \\
\text { peduli lingkungan kampung } \\
\text { payung kertas }\end{array}$ & $\begin{array}{l}\text { Peningkatan } \\
\text { kesadaran } \\
\text { lingkungan dan } \\
\text { kesehatan }\end{array}$ \\
\hline $\begin{array}{l}\text { Pintu masuk beberapa RT, } \\
\text { dekat dengan sungai }\end{array}$ & $\begin{array}{l}\text { Sampah yang } \\
\text { dihasilkan bukan hanya } \\
\text { dari warga RT } 3\end{array}$ & Pertemuan warga antar RT & $\begin{array}{l}\text { Kesepakatan } \\
\text { pengelolaan } \\
\text { sampah }\end{array}$ \\
\hline $\begin{array}{l}\text { Pengangkutan sampah tidak } \\
\text { jelas dari gerobak sampah } \\
\text { sampai pengangkuta ke } \\
\text { TPA }\end{array}$ & $\begin{array}{l}\text { Sampah menumpuk } \\
\text { dan tercampur dari } \\
\text { dalam rumah sampai di } \\
\text { gerobak }\end{array}$ & $\begin{array}{l}\text { Kerjasama dengan tukang } \\
\text { sampah, penambahan tempat } \\
\text { sampah di dalam dan luar } \\
\text { rumah, serta gerobak pilah } \\
\text { sampah. Pengelolaan sampah } \\
\text { dari dalam rumah }\end{array}$ & $\begin{array}{l}\text { Jadwal yang } \\
\text { tetap dan pasti } \\
\text { Jumlah sampah } \\
\text { yang keluar dari } \\
\text { rumah dapat } \\
\text { berkurang }\end{array}$ \\
\hline 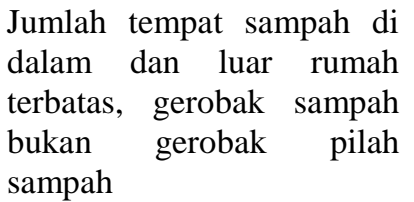 & $\begin{array}{l}\text { Sampah dicampur dari } \\
\text { dalam rumah }\end{array}$ & $\begin{array}{l}\text { Menambah jumlah tempat } \\
\text { sampah, melakukan pemilahan } \\
\text { dari dalam rumah }\end{array}$ & $\begin{array}{l}\text { Jumlah sampah } \\
\text { berkurang dan } \\
\text { tidak tercampur }\end{array}$ \\
\hline $\begin{array}{l}\text { Warga RT lain membuang } \\
\text { sampah di sungai dan } \\
\text { lingkungan }\end{array}$ & $\begin{array}{l}\text { Lingkungan RT kotor, } \\
\text { bau, menimbulkan }\end{array}$ & $\begin{array}{l}\text { Komunikasi, } \\
\text { kesepakatan }\end{array}$ & $\begin{array}{l}\text { Kerjasama yang } \\
\text { solid dalam } \\
\text { menjaga } \\
\text { lingkungan }\end{array}$ \\
\hline
\end{tabular}


Berdasarkan tabel analisis masalah dan tujuan beberapa hal sudah dicapai dalam kegiatan Doktor Mengabdi ini dan beberapa kegiatan menjadi catatan dan saran kegiatan lanjutah tahun berikutnya. Kegiatan yang telah dicapai adalah terbentuknya komunitas peduli lingkungan kampung payung kertas dengan membuat kesepakatan antar anggota komunitas, setelah komunitas terbentuk kegiatan sosialisasi, diskusi dan FGD telah dilaksanakan sampai dengan melakukan evaluasi. Selain itu penambahan tempat sampah dalam rumah sudah diberikan pada anggota komunitas dan pemberian gerobak sampah pilah. Komunitas juga sudah melakukan kerjasama dengan tukang sampah terkait jadwal dan pemilahan sampah dari dalam rumah anggota komunitas.

\section{Perubahan}

a. Sosialisasi, edukasi, dan FGD

Sosialisasi, edukasi dan FGD dilakukan dengan menyesuaikan jadwal warga seperti tahlil, arisan, dan kegiatan kampung lainnya. Kegiatan ini melibatkan 54 warga RT 3. Sosialisasi dan edukasi diberikan untuk meningkatkan kesadaran warga terkait kebersihan dan kesehatan lingkungan, setelah pemberian edukasi dilakukan
FGD terkait kebersihan dan kesehatan di lingkungan RT 3

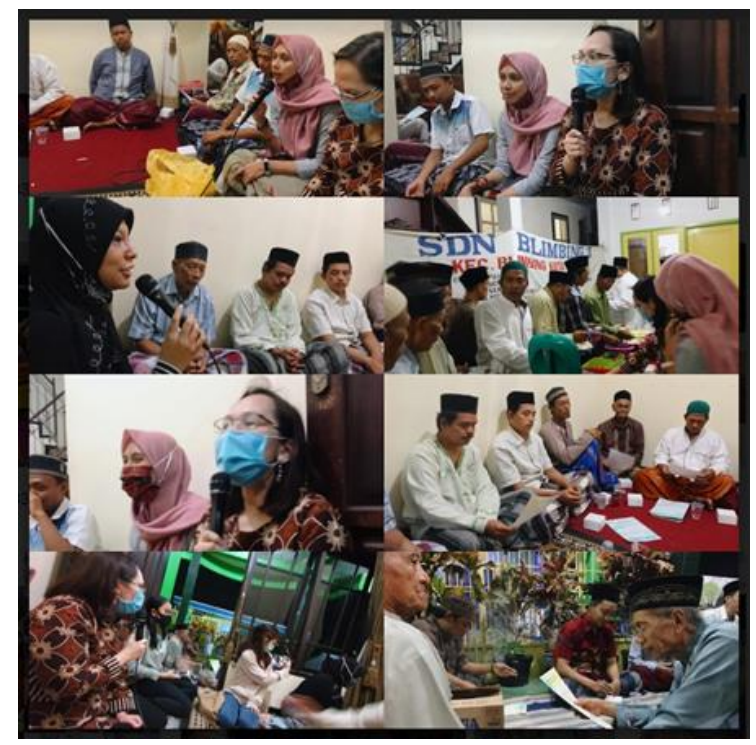

Gambar 5. Proses pendekatan komunitas dan sosialisasi

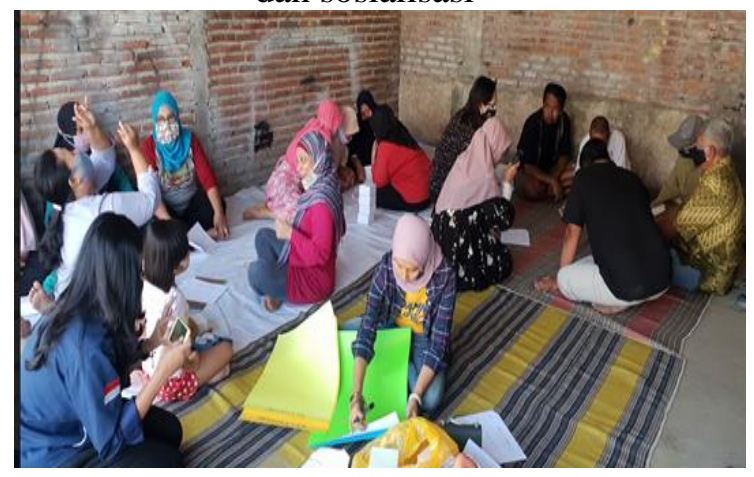

Gambar 6. Proses FGD

Untuk mempermudah proses sosialisasi dan FGD, tim menggunakan flyer yang berisi materi yang sesuai dengan tema pengabdian.

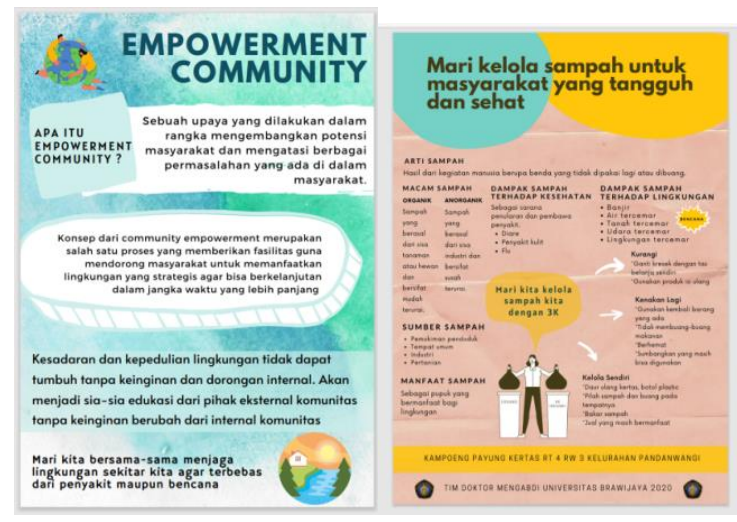

Gambar 7. Flyer sosialisasi 
b. Pelatihan Pemilahan Sampah

Pada tanggal 26 Juli 2020, dilakukan pelatihan yang bertujuan untuk melakukan praktek pemilahan sampah. Pemilahan sampah ini secara garis besar dibagi menjadi 2 bagian, yaitu sampah basah dan sampah kering. Pada kegiatan ini diikuti oleh 16 peserta yang sepakat ini menjadi bagian dari proses perubahan di kampung ini. Pada pelatihan ini disampaikan apa bahaya sampah dan bagaimana agar sampah bisa dipilah dari rumah sebelum dibawa oleh petugas kebersihan RT. Peserta dibagikan materi tentang apa yang termasuk kategori sampah basah dan apa yang termasuk kategori sampah kering. Pada kegiatan ini dibuka sesi diskusi terkait pemilahan sampah. Para peserta pelatihan melakukan praktek secara langsung untuk melakukan pemilahan sampah dan nantinya akan diterapkan di rumah masing-masing peserta pelatihan. Peserta juga diberikan tempat sampah dan alternatif pengganti tempat sampah jika tidak memiliki tempat sampah yang permanen.

\section{c. Turun Tangan}

Komunitas melakukan pemilahan sampah dari dalam rumah, diawali dari praktik saat sosialisasi berjalan. Tim doktor mengabdi secara random terus melakukan pemantauan dengan cara kunjungan ke rumah warga untuk melihat kendala maupun komitmen anggota komunitas dalam menjalankan kesepakatan yaitu pemilahan dari dalam rumah.

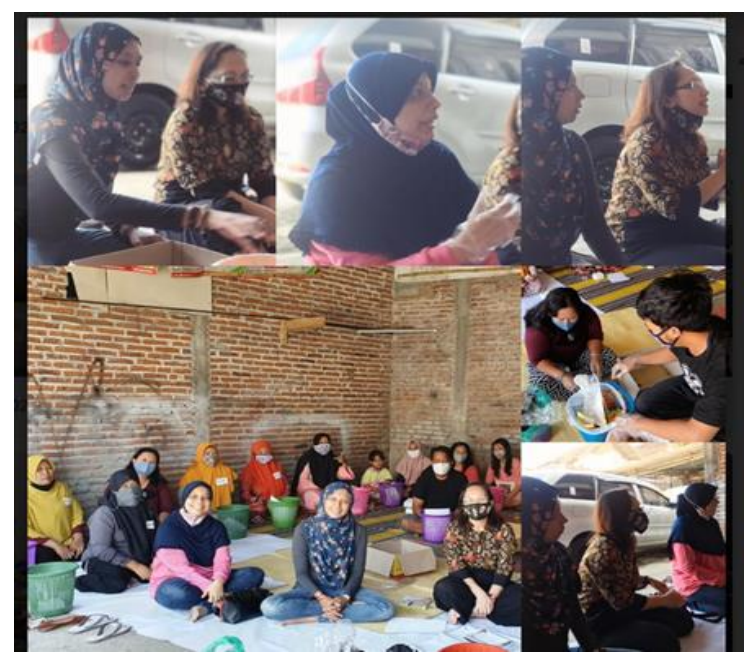

Gambar 8. Edukasi dan Pelatihan memilah sampah

Hasil yang ditemukan belum seluruh anggota komunitas melakukan pemilahan secara tertib, beberapa kali ditemui perilaku menyatukan sampah dan membakar sampah. Dibutuhkan monitoring secara terus agar perilaku menjadi kebiasaan.

d. Hasil survey

Kegiatan survey dilakukan selama 4 kali, kegiatan ini dilakukan pada tanggal 27 Juli 2020 hingga 27 Agustus 2020. Survey ini dilakukan secara tibatiba oleh tim didampingi oleh mahasiswa. Dari hasil survey diperoleh data bahwa tidak semua warga telah melakukan pemilahan sampah secara 
konsisten. Sebagian warga telah melakukan pemilahan sampah sejak lama namun hanya sebatas barangbarang yang bisa dijual kembali yang dipilih atau disendirikan untuk dijual atau diberikan kepada pemulung, seperti sampah kertas, botol plastik. Sementara sampah basah kadangkala masih bercampur dengan sampah kering. Pada minggu berikutnya, sebagian besar peserta pelatihan telah melakukan pemilahan sampah, meski ada kendala yaitu adanya pembakaran sampah oleh pasangan atau anggota keluarga lainnya yang kurang memahami makna pemilahan sampah ini. Kurang konsisten perilaku memilah sampah ini berasal dari anggota keluarga yang tidak mengikuti pelatihan, sehingga disimpulkan bahwa komunikasi yang diterapkan di rumah masih belum optimal.

Pada minggu berikutnya, sebagian warga yang mengikuti pelatihan pemilahan sampah telah melakukan pemilahan sampah basah dan kering meski masih ada sampah yang tercampur, namun perilakunya sudah menjadi lebih konsisten. Hanya saja kendala terbesar datang dari sarana sampah yang berada di depan rumah. Tempat sampah besar yang hanya satu, membuat sebagian warga akhirnya mengelompokkan lagi sampahnya di dalam satu wadah besar dan oleh petugas pengambil sampah dijadikan satu kembali di kereta sampah. Sehingga dapat disimpulkan kegiatan ini menjadi nol kembali. Oleh karena itu tim pengabdian menyimpulkan bahwa harus diadakan FGD dan kesepakatan serta pembuatan kereta sampah yang telah disekat untuk memilah sampah kering dan basah di dalam kereta sampah.
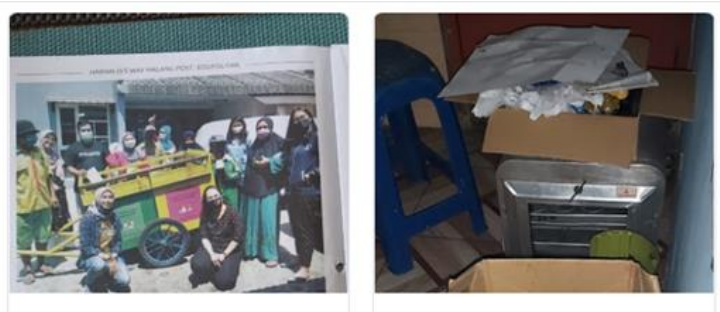

ـ publikasi di koran.jpeg

ص survey 1_1.jpeg

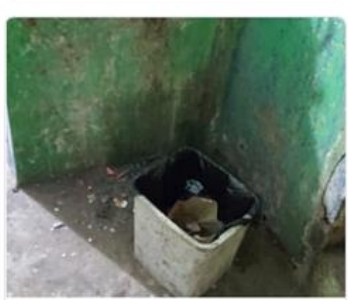

a survey 1_4.jpeg

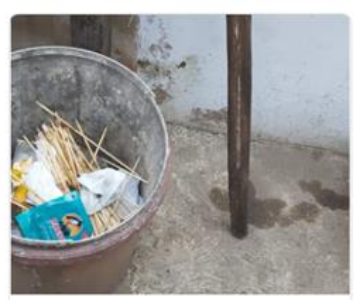

ص survey 1_5.jpeg
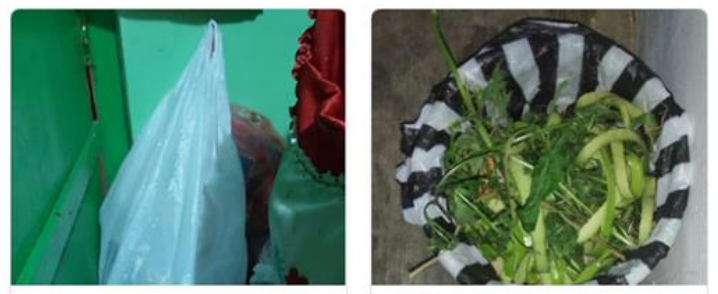

a survey 1_2.jpeg

ـ survey 1_3.jpeg

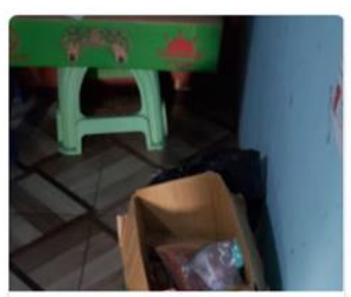

ص survey 1_6.jpeg

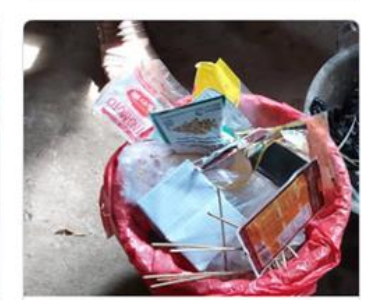

survey 1_7.jpeg

Gambar 9. Survey dan monitoring rutin perilaku memilah sampah 


\section{PEMBAHASAN}

Evaluasi yang dilakukan untuk mengukur tingkat keberhasilan kegiatan ini adalah dengan:

a. Pretest dan Posttest

Pretest dan posttest diberikan pada 11 anggota komunitas untuk mengukur perubahan yang terjadi selama masa sosialisasi sampai evaluasi, hal ini bertujuan untuk mengukur keberhasilan program. Terdapat lima hal yang diukur perubahannya yaitu jumlah tempat sampah dalam rumah, perilaku memilah sampah dari dalam rumah, pola membuang sampah, jumlah sampah yang dihasilkan, dan pengetahuan terkait kebersihan dan kesehatan. Berdasarkan hasil pretest dan posttest terhadap 11 warga, lima warga menunjukan peningkatan pengetahuan, sikap dan perilaku dalam pengelolaan sampah, lima orang tidak menunjukan perubahan sama sekali dan satu orang justru menunjukan penurunan sikap dan perilaku pengelolaan sampah.

Hal ini menunjukan bahwa monitoring tetap harus dilakukan sampai perubahan secara permanen terbentuk. Dari hasil FGD disebutkan kesulitan memilah sampah akibat tidak tertib, kurang berani saling tegur bila tidak melakukan perubahan dan merasa percuma melakukan pemilahan karena akan dijadikan satu oleh tukang sampah di gerobak. Hal ini menjadikan dasar melakukan kesepakatan dengan tukang sampah sekaligus menyediakan gerobak sampah pilah.

b. Analisis SWOT

Evaluasi dilakukan dengan menggunakan analisis SWOT dengan mengevaluasi kebijakan atau strategi dengan menggunakan kekuatan (strength) dan kelemahan (weakness), peluang (opportunities) dan ancaman (threats) komunitas. Analisis SWOT pertama kali diperkenalkan oleh Albert S Humphrey pada tahun 1960-an pada saat memimpin proyek riset di Stanford Research Institute yang menggunakan basis data dari perusahaan-perusahaan Fortune 500.

Melalui analisis SWOT dapat ditemukan masalah dari empat sisi yang berbeda, di mana aplikasinya adalah bagaimana kekuatan (strengths) mampu mengambil keuntungan dari sebuah peluang (opportunities) yang ada, bagaimana cara mengatasi kelemahan (weaknesses) yang mencegah keuntungan, bagaimana kekuatan (strengths) mampu menghadapi ancaman (threats) yang ada dan bagaimana cara mengatasi kelemahan (weaknesses) yang mampu membuat 
ancaman (threats) menjadi nyata atau menciptakan sebuah ancaman baru.

Hubungan empat faktor tersebut, membuat analisis ini memberikan kemudahan untuk mewujudkan visi dan misi organisasi, komunitas atau perusahaan. Analisis SWOT mengatur kekuatan, kelemahan, peluang, dan ancaman utama komunitas ke dalam daftar yang terorganisir. Strengths (S) yaitu kekuatan dan Weaknesses (W) atau kelemahan merupakan faktor yang berasal dari internal komunitas, hal-hal yang dapat dikontrol dan dapat berubah. Contohnya termasuk siapa yang ada di tim, paten dan properti intelektual, dan lokasi komunitas. Opportunities (O) atau peluang dan Threats (T) atau ancaman adalah faktor eksternal yang mempengaruhi bisnis atau hal-hal yang terjadi di luar komunitas. Memahami faktor eksternal dapat dimanfaatkan untuk melihat peluang dan melindungi dari ancaman, tetapi Anda tidak dapat mengubahnya. Contohnya termasuk pesaing, harga bahan baku, dan tren belanja pelanggan dan lainnya sesuai dengan permasalahan komunitas. Detail faktor eksternal dan internal dapat dijelaskan di bawah ini.

Dua faktor pokok yang akan memengaruhi keempat komponen dasar pada analisis SWOT, yaitu:
1) Faktor Internal (Strength dan Weakness)

Faktor internal atau faktor yang berasal dari dalam terdiri dari dua poin yaitu kekuatan dan kelemahan. Keduanya akan berdampak lebih baik dalam sebuah penelitian ketika kekuatan lebih besar dibandingkan kelemahan. Dengan demikian kekuatan internal yang maksimum jelas akan memberikan hasil penelitian yang jauh lebih baik. Adapun bagian bagian dari faktor internal itu sendiri, antara lain sumber daya yang dimiliki, keuangan atau finansial, kelebihan atau kelemahan internal organisasi, serta pengalaman-pengalaman organisasi sebelumnya (baik yang berhasil maupun yang gagal).

2) Faktor Eksternal (Opportunities dan Threats)

Faktor dari luar komunitas, faktor yang tidak secara langsung terlibat pada apa yang sedang. Adanya peluang serta ancaman akan memberikan data yang harus dimasukkan dalam jurnal penelitian sehingga menghasilkan strategi untuk menghadapinya. Beberapa poin yang termasuk pada faktor eksternal, antara lain tren, budaya, sosial politik, ideologi, maupun 
perekonomian, sumber-sumber permodalan, peraturan pemerintah, perkembangan teknologi, peristiwaperistiwa yang terjadi, dan lingkungan.

Analisis ini dapat digunakan pula oleh stakeholder untuk mengetahui gambaran kondisi faktor internal dan eksternal dari organisasi, komunitas atau perusahaan. Penilaian SWOT ini membantu komunitas, perusahaan dan organisasi untuk menetapkan prioritas mana saja yang harus didahulukan oleh komunitas, perusahaan dan organisasi, apakah hal itu berasal dari internal ataukah dari faktor eksternal perusahaan. Tanpa adanya informasi tersebut, perusahaan, komunitas atau organisasi tidak dapat mengetahui seberapa besar potensi pasar, minat dan peluang pasar yang dapat dimanfaatkan, serta tingginya tingkat persaingan pasar pada produk atau usaha.

\section{Tujuan Analisis SWOT} adalah untuk menemukan aspekaspek penting dari kekuatan, kelemahan, peluang, dan ancaman di dalam suatu perusahaan atau organisasi. dari keempat aspek tersebut, diharapkan mampu memaksimalkan

kekuatan, meminimalisir kelemahan, ancaman, dan memperluas peluang-peluang di masa depan. Penilaian SWOT ini hanyalah sebuah alat analisis yang ditujukan untuk menggambarkan situasi yang dihadapi atau yang mungkin akan dihadapi di masa mendatang oleh perusahaan dan organisasi.

Analisis SWOT tidak dapat dikerjakan seorang diri, dibutuhkan tim dalam membahas analisis SWOT. Kumpulkan orang-orang dari berbagai bagian komunitas dan pastikan berasal dari setiap bagian komunitas. Berbagai kelompok dalam komunitas dapat memiliki perspektif yang sama sekali berbeda yang dibutuhkan dalam membuat analisis SWOT. Membentuk kelompok-kelompok diskusi kecil untuk melakukan brainstorming. Melakukan analisis SWOT mirip dengan pertemuan mendengarkan pendapat, untuk mengetahui cara yang benar dan salah dalam menjalankan suatu hal. Disarankan untuk meminta setiap orang mencatat dan minta setiap orang diam-diam menghasilkan ide untuk memulai sesuatu. Hal ini untuk mencegah groupthink dan memastikan bahwa semua suara didengar. 
Setelah

melakukan

brainstorming selama lima hingga 10 menit, letakkan semua catatan dan tempel di dinding jangan lupa untuk mengelompokkan ide-ide serupa. Izinkan siapapun menambahkan catatan tambahan pada titik ini jika ide orang lain memicu pemikiran baru. Setelah semua ide diorganisasikan, sekarang saatnya untuk menentukan peringkat ide. gunakan sistem pemungutan suara di mana setiap orang mendapat lima atau sepuluh "suara" yang dapat mereka bagikan dengan cara apa pun yang mereka suka. Membuat catatan dalam berbagai warna berguna untuk latihan ini.

\section{Analisis SWOT dapat} memfokuskan diri pada satu kombinasi dari dua poin dari SWOT untuk menentukan langkah strategis yang dibutuhkan. Kombinasi fokus tersebut antara lain:

Fokus pada kekuatan-peluang (S-O) untuk memperoleh alternatif ofensif dengan menggunakan kekuatan internal untuk memanfaatkan peluang eksternal, fokus pada Kelemahan-ancaman (WT) untuk memperoleh alternatif defensif dengan memanfaatkan kelemahan internal untuk mengurangi ancaman eksternal, fokus pada Kekuatan-ancaman (S-T) dengan menggunakan kekuatan internal untuk mengurangi ancaman eksternal, ataupun fokus pada Kelemahan-peluang (W-O) dengan menopang kelemahan internal untuk mengambil keuntungan dari kesempatan eksternal.

Sebagaimana sebuah metode pada umumnya, analisa SWOT ini hanya dapat membantu menganalisa situasi yang sedang dihadapi oleh perusahaan atau sebuah organisasi bukan sebuah jawaban pasti yang mampu memberikan solusi pada tiap masalah yang sedang dihadapi, namun minimal akan memecah persoalan yang ada dengan menguraikan menjadi bagian-bagian kecil yang akan lebih tampak sederhana. 
Tabel 3. Hasil analisis SWOT

\begin{tabular}{|c|c|c|}
\hline & $\begin{array}{l}\text { HELPFUL (POSITIF) } \\
\text { Untuk mencapai tujuan }\end{array}$ & $\begin{array}{l}\text { HARMFUL (NEGATIF) } \\
\text { Untuk mencapai tujuan }\end{array}$ \\
\hline $\begin{array}{l}\text { INTERNAL } \\
\text { Atribut } \\
\text { komunitas }\end{array}$ & $\begin{array}{l}\text { Strengths- kekuatan komunitas } \\
\text { 1. Sudah memiliki tempat sampah di } \\
\text { salam dan di luar rumah masing- } \\
\text { masing } \\
\text { 2. Memiliki pengetahuan dan } \\
\text { pemahaman cara memilah sampah } \\
\text { dengan baik } \\
\text { 3. Lingkungan bersih } \\
\text { 4. Mulai sadar memilah sampah } \\
\text { 5. Guyub dan patuh pada keputusan } \\
\text { kelompok } \\
\text { 6. Lokasi kampung di depan, memiliki } \\
\text { jalan masuk/ pintu utama untuk } \\
\text { kampung lain } \\
\text { 7. Memiliki lapangan } \\
\text { 8. Budaya gotong royong tinggi }\end{array}$ & $\begin{array}{l}\text { Weaknesses- kelemahan komunitas } \\
\text { 1. Tempat sampah di luar rumah hanya } \\
\text { satu padahal dari rumah sudah } \\
\text { dipilah, sampai luar rumah digabung } \\
\text { kembali antara sampah basah dan } \\
\text { kering } \\
\text { 2. Banyak yang lupa dan malas } \\
\text { memilah } \\
\text { 3. Kurang kesadaran memilah sampah } \\
\text { 4. Komunikasi kelompok masih kurang, } \\
\text { segan untuk saling mengingatkan } \\
\text { 5. Memiliki kesibukan yang } \\
\text { menyulitkan berkomunikasi } \\
\text { 6. Tidak memanfaatkan teknologi } \\
\text { dalam berkomunikasi (group wa dll) }\end{array}$ \\
\hline $\begin{array}{l}\text { EKSTERNAL } \\
\text { Atribut } \\
\text { lingkungan/ di } \\
\text { luar komunitas }\end{array}$ & $\begin{array}{l}\text { Opportunities - potensi lingkungan } \\
\text { 1. Warga lain banyak yang parkir di } \\
\text { lahan komunitas } \\
\text { 2. Belum ada pemilahan sampah di } \\
\text { kampung lain } \\
\text { 3. Memiliki akses/ jalan masuk bagi } \\
\text { kampung lain } \\
\text { 4. Belum ada program bank sampah di } \\
\text { lingkungan kampung lain } \\
\text { 5. Belum ada gerobak sampah terpilah } \\
\text { 6. Belum ada teknologi yang digunakan } \\
\text { untuk memonitor perilaku } \\
\text { pengelolaan sampah warga kampung } \\
\text { maupun luar kampung } \\
\text { 7. Ada dukungan dari kelurahan untuk } \\
\text { gerakan peduli lingkungan }\end{array}$ & $\begin{array}{l}\text { Threats - tantangan lingkungan } \\
\text { 1. Kampung lain di sekitar masih } \\
\text { membuang sampah di sungai } \\
\text { 2. Banyak industri rumah tangga di luar } \\
\text { komunitas yang tidak mengelola } \\
\text { sampah dan langsung membuang } \\
\text { sampah di sungai (usaha tahu, } \\
\text { pemotongan ayam, dan lainnya) } \\
\text { 3. Belum ada lahan parkir untuk } \\
\text { gerobak sampah } \\
\text { 4. Jadwal pengambilan sampah yang } \\
\text { kurang rutin } \\
\text { 5. Jadwal pengangkutan ke TPA tidak } \\
\text { pasti } \\
\text { 6. Di dalam rumah di pilah, di TPS, } \\
\text { gerobak sampah, TPA digabung } \\
\text { kembali }\end{array}$ \\
\hline
\end{tabular}

Fokus pada kekuatan-peluang (S-O) untuk memperoleh alternatif ofensif dengan menggunakan kekuatan internal untuk memanfaatkan peluang eksternal. Pada analisis SWOT ini komunitas berfokus pada Strenght dan Opportunities yang dimiliki komunitas. Komunitas memiliki kekuatan suudah memiliki kesadaran, keterampilan dan mulai membiasakan memilah sampah dari dalam rumah, memiliki tempat sampah di salam dan di luar rumah masing-masing, selain itu komunitas terdiri dari warga yang guyub dengan kepemimpinan yang 
mengayomi dan disegani sehingga

lebih mudah untuk mengajak warga melakukan perubahan. Lokasi RT 04 yang berada di depan dan memiliki lapangan sebagai lahan kosong yang bisa dimanfaatkan warga RT 04 dan RT lain, menjadikan kampung payung kertas menjadi pintu utama beberapa RT di belakangnya sekaligus kekuatan dalam mendorong kampung lain ikut melakukan perubahan.

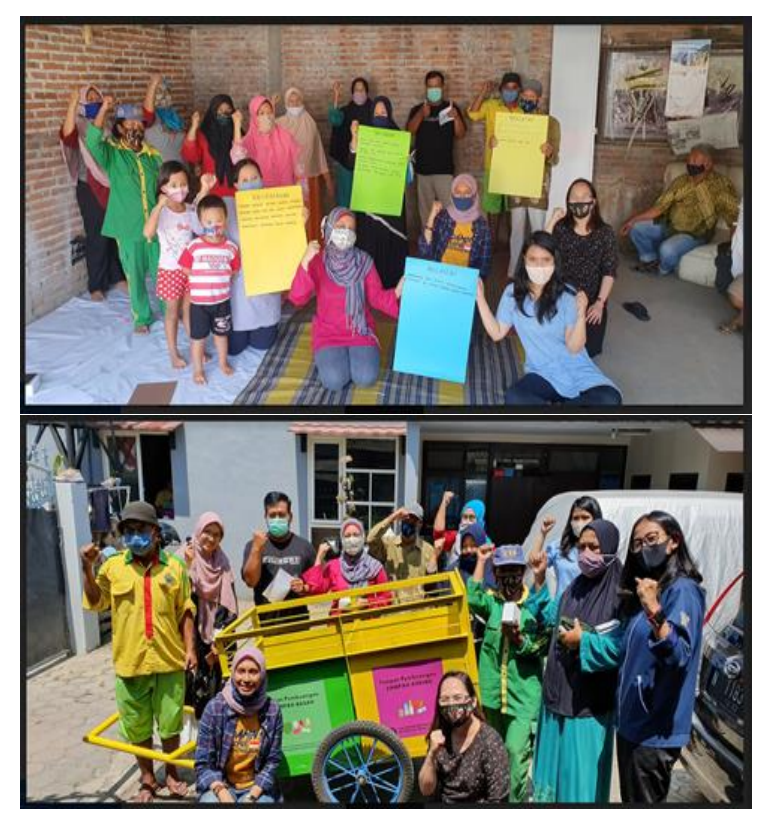

Gambar 10. Hasil dan proses analisis SWOT dan serah terima gerobak sampah

\section{SIMPULAN}

Kegiatan membentuk empowerment community pada warga kampung payung kertas telah berhasil dilakukan dengan menjadikan komunitas peduli lingkungan kampung payung kertas sebagai motor perubahan di kampung RT 04. Kegiatan yang dilakukan untuk memperkuat komunitas adalah dengan melakukan pemilahan sampah dari dalam rumah, menambah fasilitas tempat sampah di dalam dan di luar rumah serta gerobak pilah sampah.

\section{SARAN}

Empowerment community akan lebih berhasil bila ada tindakan berkelanjutan yang dilakukan oleh komunitas. Berdasarkan hasil yang telah dicapai dan beberapa kesempatan kegiatan yang dapat dilakukan, sebaiknya untuk kegiatan pengabdian masyarakat selanjutnya memperkuat komunitas peduli lingkungan dengan kegiatan rutin bersama seperti gotong royong kebersihan bersama secara berkala, melakukan pengolahan lebih lanjut pada sampah basah seperti dengan membuat kompos, penghijauan kampung, bank sampah dan lainnya. Selain itu beberapa tindakan lanjutan harus dilakukan untuk menghindari konflik dengan komunitas lain yaitu melakukan kesepakatan dengan warga RT lain terkait perilaku membuang sampah, bekerjasama dengan karang taruna untuk proses pengelolaan sampah komunitas peduli lingkungan.

\section{UCAPAN TERIMA KASIH}

Tim pengabdian Doktor Mengabdi mengucapkan banyak terimakasih kepada 
seluruh warga Kampung Payung Kertas, Bapak RT 03 yang bersedia membentuk komunitas Peduli Lingkungan Kampung Payung Kertas Malang untuk bergerak memulai pemilahan sampah dari dalam rumah. Selain itu terimakasih kami ucapka sebesar-besarnya kepada pihak Kelurahan Pandanwangi yang bersedia bermitra untuk mencapai perubahan sosial ini.

\section{DAFTAR PUSTAKA}

Afandi, A., Neolaka, A., \& Saleh, R. (2012). Kesadaran lingkungan masyarakat dalam pemeliharaan taman lingkungan di Jakarta Pusat. Menara: Jurnal Teknik Sipil, 7(1), 14-14.

Anckermann, S., Dominguez, M., Soto, N., Kjaerulf, F., Berliner, P., \& Naima Mikkelsen, E. (2005). Psychosocial support to large numbers of traumatized people in post-conflict societies: An approach to community development in Guatemala. Journal of Community \& Applied Social Psychology, 15(2), 136-152.

Asmara, D. T., \& Nugroho, T. E. (2017). Pengaruh Pemberian Analgesik Kombinasi Parasetamol Dan Tramadol Terhadap Kadar Serum Glutamat Oksaloasetat Transaminase Tikus Wistar.
DIPONEGORO MEDICAL

JOURNAL (JURNAL

KEDOKTERAN DIPONEGORO), 6(2), 417-426.

Bond, M. A., \& Keys, C. B. (1993). Empowerment, diversity, and collaboration: Promoting synergy on community boards. American Journal of Community Psychology, 21(1), 37-57.

BPBD Kota Malang. (2019). SEPANJANG 2019, 119 BANGUNAN RUSAK AKIBAT BENCANA. https://bpbd.malangkota.go.id/2020/ 01/01/sepanjang-2019-114bangunan-rusak-akibat-bencana/ Cahyono, S. (2018). 26 Titik Sungai di Kota Malang Tercemar. https://www.jawapos.com/jpgtoday/07/03/2018/26-titik-sungaidi-kota-malang-tercemar/

Fawcett, S. B., White, G. W., Balcazar, F. E., Suarez-Balcazar, Y., Mathews, R. M., Paine-Andrews, A., Seekins, T., \& Smith, J. F. (1994). A contextual-behavioral model of empowerment: Case studies involving people with physical disabilities. American Journal of Community Psychology, 22(4), 471-496.

Hairunisya, N. (2017). Pelatihan dan pendampingan pembuatan laporan 
keuangan kepada pengusaha umkm

di kecamatan karangrejo kabupaten

tulungagung. J-ADIMAS (Jurnal

Pengabdian Kepada Masyarakat), $5(2)$.

Pranaka, A. M. W., \& Prijono, O. S.

(1996). Pemberdayaan Masyarakat.

Yogyakarta: Pustaka Pelajar. 